\title{
Development of Group-Based Differentiated Learning (GBDL) Models
}

\author{
Toto Ruhimat ${ }^{*}, 1$, Deni Darmawan ${ }^{2}$ \\ ${ }^{1}$ Curriculum and Educational Technology, Department, Universitas Pendidikan Indonesia, Bandung, 40154, Indonesia \\ ${ }^{2}$ Educational Technology and Communication Science, Department Universitas Pendidikan Indonesia, Bandung, 40154, Indonesia
}

\begin{tabular}{l} 
A R T I C L E I N F O \\
\hline Article history: \\
Received: 17 August, 2020 \\
Accepted: 15 October, 2020 \\
Online: 08 November, 2020
\end{tabular}

Keywords:

Differentiated Group Learning

Thinking Ability

Social Ability

\begin{abstract}
A B S T R A C T
The ability to think and the social abilities of junior high school students is a potential ability developed through learning based on the optimization of differences in learning abilities. For this reason, appropriate learning design and implementation model is needed in realizing this, especially in one of the social group subjects. This study uses research and development methods that begin with a preliminary study, develops a draft model, tests, and experiments to test model validation. Data collection techniques with observation, experimentation, and interviews. The results showed that aspects of the model of differentiated learning design based on groups put forward the process of analyzing the characteristics of students about readiness, interests learning profile, flexibility for curriculum elements of content (content), process (process), and results (product). Learning objectives are developed in the form of measurable and specific abilities that describe student behavior. In particular, the learning design components include; (a) Analysis of characteristics and curriculum elements; (b) Learning objectives or competencies to be achieved; (c) Essential material; (d) Learning Process, and (e) Learning Evaluation. The Implementation Model is carried out through learning syntax, namely: orientation, general exploration, learning techniques, investigation, evaluation, and follow-up. Group learning model, in which students learn individually to collaborate in the first group after completing the second group, after the second group rejoining the first group.
\end{abstract}

\section{Introduction}

Improving quality in the National Education System should be in line with globalization, which has an impact on changes in social life, political science, and technology in various countries quickly. Globalization has several impacts, including free markets, cooperation and competition between countries, democracy, and the implementation of human rights. This is in line with [1], which focused on Intelligence, Globalization, Complex, and Multi-Level Society. These forces have implications for national education, particularly in the effectiveness and relevance of the education system. It also relates to the need for efficiency, innovative, and creative movements in improving education quality.

To realize the education quality, schools need to develop attitudes, abilities and provide essential knowledge and skills

\footnotetext{
${ }^{*}$ Corresponding Author: Toto Ruhimat, Indonesia University of Education, Street of Dr. Setiabudi, 229 Bandung, 40154, Phone (022)2013163, email: toto.ruhimat@upi.edu
}

needed to live in a global society. Learning needs to be pursued based on an individual approach, though it does not neglect the students' social abilities (sociability), such as relationships with peers, cooperative, tolerance, and respect the opinion of others. The learning characteristics are in line with the concept of a democratic education that uses a scientific approach both in groups and individually [2], [3]. According to [4], individuals have differences in intelligence diversity, and student's potential needs attention [5].

Learning methods need to be developed based on the characteristics that accommodate student differences. Their implications need to be flexible and oriented towards the formation of diverse competencies in students. Learning should focus on optimizing students' abilities individually and prioritize their differences. Moreover, learning activities should be flexible and dynamic, democratic, fun, and active [6]. Essential material that needs to be developed in diverse learning can be classified based on the level of learning, such as the classification of facts, 
concepts, principles, attitudes, and skills [7]. In the selection of subject matter, it is necessary to pay attention to the balance of ethics, logic, aesthetics, and kinesthetic. It is vital to ensure that the subject matter is developed as expected.

The preliminary study on learning with the above competencies in the Social Sciences established that most junior high school students felt the learning process was not optimal, especially the method used, development of learning materials, the use of time, and the utilization of media as learning resources. The learning process tends to be expository or informative, and therefore students are more positioned learning objects.

Learning should prioritize the needs and differences of students based on the desired outcomes. This relates to the aspects of readiness, interests, needs, and learning profiles of students [7]. These aspects can be used as a basis for student differences. The results of these aspects are useful in developing education programs and determining learning materials and approaches, such as group learning, which develops students' social abilities, including cooperation, tolerance, and understanding the opinions of others. Additionally, it provides opportunities for students to recognize and develop their abilities based on multiple intelligences [8]. In this context, [9] established that learning involves 4 variables, including presage, context, process, and product.

Based on the background description, it is necessary to research and develop learning models that optimize the thinking and social abilities of students corresponding to differences in individual potential. This means that the resulting learning model needs to appreciate, accommodate, and facilitate the potential of students individually without neglecting social abilities. Therefore, this study focuses on the following questions (1) What kind of group learning design model optimizes students' thinking and social abilities based on their potential? ; (2) What kind of learning implementation model optimizes students' thinking and social abilities based individual potential ?; and (3) What kind of learning environment standards can optimize students' thinking and social abilities based on individual potential?.

\section{Theoretical Review}

\subsection{The Essence of Student Differences}

Students are individuals with unique differences from each other. [2] identified individual differences based on the multiple intelligences. The pattern of multiple intelligences is a form of curriculum organization that can be independently developed and guided by each individual. It can as well be perceived as an essential ability of each individual, which needs to be developed early for future survival. The characteristics of gifted students[10] can be identified from the abilities possessed, such as (1) general intellectual, (2) specific academic aptitude, (3) creative or productive thinking, (4) leadership skills, (5) visual and performing arts, (6) psychomotor abilities. According to Renzulli, a minimum of 3 to 5 percent of the students in schools have this ability.

\subsection{Learning Procedures for the Development of Social Ability}

The development of effective social abilities can be carried out using group or cooperative learning. [11] established that the teaching model can be grouped into 4, including information processing, personal, social, and behavioral groups. All student activities in learning programs have to be democratic, meaning that the learning process should develop the ability as individuals and have a beneficial social ability, which is beneficial for students. According to [12], social ability [13], including interpersonal intelligence, involves understanding and interacting with others.

The group learning approach is an alternative that can be developed in this regard. The stages of group investigation learning include (1) Students encounter puzzling situation (planned or unplanned); (2) exploring reactions to the situation; (3) formulating study tasks and organize for study (problem definition, role, assignment); (4) independent and group study; (5) analyzing progress and process and recycle activity [14].

Stages of learning are developed in ways that demand problemsolving and inquiry in learning. In general, students are organized into democratic problem-solving groups that attack academic problems and are taught procedures and scientific methods of inquiry [15]. This is in line with the concept of the group investigation approach, which involves placing students in the context of a social system with democratic and cooperative processes and provides opportunities for individuals to learn optimally. According to [16] students are provided the opportunity to learn based on higher-order thinking processes such as analytical, hypothesis, and scientific, especially in the learning process through problem-solving and inquiry. Cooperative learning is organized to conduct student activities in small groups in collaboration between students in learning [12].

\section{Research Method}

This study used research and development methods in education [17]. The implementation started from a preliminary study, developing a draft model, and testing and conducting experiments for model validation. Data collection techniques used include observation, experimentation, and interviews, while Relevant, Observable, useful, Realizable, Understandable, and demand by teachers and students tests were used for analysis.

Table 1: Research Samples Size

\begin{tabular}{|c|l|l|l|}
\hline No & \multicolumn{1}{|c|}{ Name of School } & \multicolumn{1}{|c|}{ Status } & \multicolumn{1}{|c|}{ Size } \\
\hline 1 & $\begin{array}{l}\text { State Junior High } \\
\text { School 15 }\end{array}$ & Experiment class & 46 \\
\hline 2 & $\begin{array}{l}\text { State Junior High } \\
\text { School 10 }\end{array}$ & Experiment class & 46 \\
\hline 3 & $\begin{array}{l}\text { State Junior High } \\
\text { School 11 }\end{array}$ & Control Class & 46 \\
\hline 4 & $\begin{array}{l}\text { Nugraha Junior High } \\
\text { School }\end{array}$ & Control Class & 46 \\
\hline \multicolumn{2}{|l|}{ Total Sample } & 184 \\
\hline
\end{tabular}

There were several reasons for choosing and using the junior high school level, including 1) according to the level of cognitive ability development, junior high school students ( between 11-15 years old) have learned to think scientifically or rationally; 2) based on the level of social ability development, junior high school students can be independent, collaborate, socialize, lead and be responsible in groups; 3 ) junior high school students can carry out group activities; 4) their curriculum contains social science subjects especially geography; 5) in the social science curriculum 
objectives, students need to develop the ability to reason, understand and solve problems; 6) social sciences allow variety, flexibility, and modification of learning content, process or product; and 7) junior high school already has a Subject Teacher Forum. Assessment technique of thinking and social abilities referred to the [18] model. The analysis data was used throughquantitative techniques with correlations, t-tests, and percentages.

\section{Result and Discussion}

\subsection{Differentiated Group Learning Model Design}

From the testing results conducted during the Research \& Development [19], a learning design model matrix for Differentiated Group learning is formulated as follows.

Table 2: Syntax of Learning Design Stage

\begin{tabular}{|c|c|c|}
\hline Component & Development Aspects & Criteria \\
\hline $\begin{array}{l}\text { Learning } \\
\text { Material }\end{array}$ & $\begin{array}{l}\text { - } \begin{array}{l}\text { Patterns of economic activity based on land use and region } \\
\text { - }\end{array} \text { Distribution of forestry in Indonesia } \\
\text { - } \\
\text { - }\end{array}$ & $\begin{array}{l}\text { - Facilitating the choices of subject } \\
\text { matter } \\
\text { - Use various sources } \\
\text { - Problem-based content } \\
\text { - The material tends to be sought, } \\
\text { built, or compiled by students } \\
\text { - Contextual }\end{array}$ \\
\hline $\begin{array}{l}\text { Learning } \\
\text { Activity }\end{array}$ & $\begin{array}{l}\text { Development of Learning Design with Stages } \\
\text { Orientations : } \\
\text { The teacher creates the initial conditions for learning Social } \\
\text { Sciences } \\
\text { The teacher conveys topics or sub-problems to be } \\
\text { discussed on the patterns of economic activity based on } \\
\text { land use and region } \\
\text { The teacher implements apperception, and students are } \\
\text { allowed to ask questions or answer related to patterns of } \\
\text { economic activity based on land use and region } \\
\text { The teacher provides a stimulus to be active in studying, } \\
\text { discussing, and learning individually or in groups } \\
\text { General exploration } \\
\text { The teacher conveys a general description of the patterns of } \\
\text { economic activity based on land use and region, explained } \\
\text { in general to the sub-topics discussed } \\
\text { The teacher provides stimulus, motivation, and attention to } \\
\text { students } \\
\text { Mastery of Learning Techniques } \\
\text { (If students have mastered the learning technique, then this } \\
\text { stage the teacher does not need to explain again unless deemed } \\
\text { necessary) } \\
\text { The teacher explains learning techniques individually and } \\
\text { in groups (cooperative) } \\
\text { The teacher explains effective learning individually and } \\
\text { cooperatively } \\
\text { The teacher explains the stages of problem-solving or } \\
\text { inquiry or group study. }\end{array}$ & $\begin{array}{l}\text { The design of learning activities } \\
\text { applies to the following principles : } \\
\text { 1. Competency-oriented: the } \\
\text { design of student activities is } \\
\text { aimed at achieving competence } \\
\text { in learning purpose } \\
\text { 2. Problem-based learning: the } \\
\text { design of student activities } \\
\text { should be based on problems } \\
\text { and issues to be studied. } \\
\text { Individual learning in a group. } \\
\text { Student activities are designed } \\
\text { individually and collaborate in } \\
\text { groups } \\
\text { Students understand individual } \\
\text { and group learning techniques. } \\
\text { The teacher designs the } \\
\text { implementation of activities, } \\
\text { students should understand the } \\
\text { learning techniques to be } \\
\text { pursued } \\
\text { Flexibility. Both individual and } \\
\text { group studies should be clear to } \\
\text { students but can be flexible and } \\
\text { modifiable } \\
\text { Position of teacher activity: } \\
\text { facilitator and resource person } \\
\text { collaborating }\end{array}$ \\
\hline
\end{tabular}




\begin{tabular}{|c|c|c|}
\hline $\begin{array}{l}\text { Learning } \\
\text { Activity }\end{array}$ & 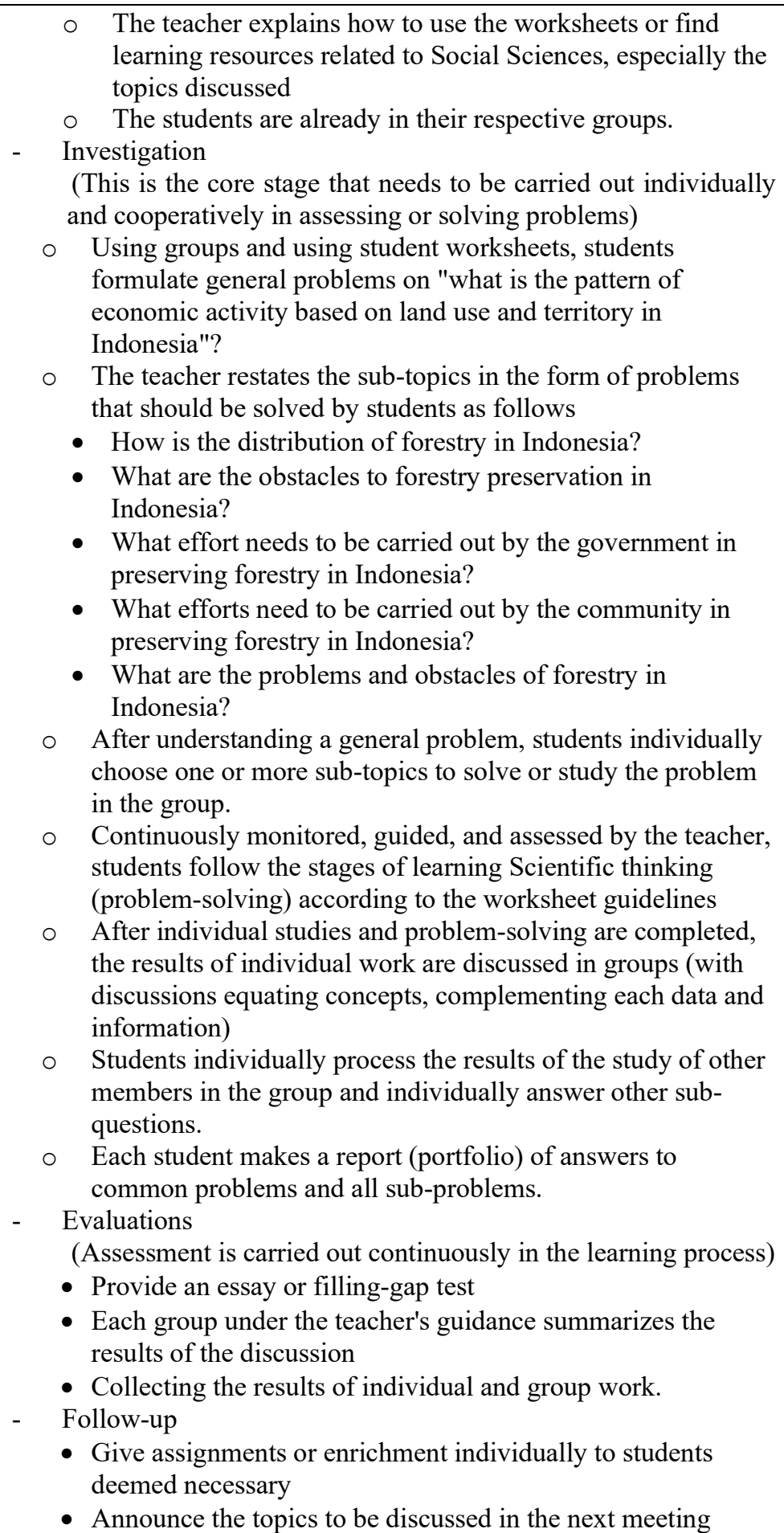 & \\
\hline $\begin{array}{l}\text { Learning } \\
\text { Outcomes }\end{array}$ & $\begin{array}{l}\text { Assessment Procedure The assessment is carried out continuously } \\
\text { IInnitial, process, and final tests Types of Assessment Forms, The } \\
\text { assessment uses observation, written, oral, and portfolio forms. }\end{array}$ & $\begin{array}{l}\text { - The assessment design prioritizes } \\
\text { to assess the learning process } \\
\text { apart from the input and results. } \\
\text { - Assessment is designed as a basis } \\
\text { for improvement, enrichment, and } \\
\text { diagnostics. } \\
\text { - The results of the assessment as a } \\
\text { modifiable elements. Portfolio } \\
\text { assessment. } \\
\text { - Group and individual activities }\end{array}$ \\
\hline
\end{tabular}


The Group-Based Differentiated Learning Design was developed based on the aspects of Learning syntax as follows; (a) Analysis of students' characteristics of interest, readiness, and learning profile; (b) Analysis of curriculum elements (content, process, and product) that can be modified; (c) Conditions of the learning environment; (d) Assessment is designed continuously and integrated; (e) Objectives formulated and developed in the form of abilities; (f) Development of learning activities refers to the stages of orientation, general exploration, mastery of learning techniques, investigation, evaluation, and follow-up; (g) The curriculum components in learning design prioritizes the components of objectives, the content of subject matter, learning activities, and evaluation of learning developed systematically and systemically; (h) The format of the learning design can be developed flexibly depending on the needs of developing learning programs and the applicable curriculum. This finding is in line with [16], which focused on the balancing acts of building positive relationships with students.

Student Grouping Design was carried out in 2 stages, the first and the second groups. The first group resolves general problems with individuals who collaborate, and the product is a general problem-solving portfolio. This finding is supported by[16], which stated that learning outcomes serve as references for preceding teaching and assessment activities that help students construct learning. Furthermore, students in the first group choose one or two sub problems to be studied more deeply in the second group whose members chose the same sub-problem. The product of this second group is the portfolio of individual studies on selected sub-problems. Once the second group is completed, students return to join the first group to study and formulate more profound conclusions on the general problems.

Table 3: Syntax of Learning Implementation

\begin{tabular}{|c|c|c|}
\hline Procedure & Details & Teacher's Scenario \\
\hline \multirow[t]{4}{*}{$\begin{array}{l}\text { Orientation } \\
\text { (1) }\end{array}$} & $\begin{array}{l}\text { Creating conditions for } \\
\text { effective learning }\end{array}$ & $\begin{array}{l}\text { - It starts from the beginning of learning by creating a } \\
\text { conducive classroom atmosphere for readiness to take } \\
\text { lessons. } \\
\text { - Direct the concentration of students and encourage them } \\
\text { to be interested in learning. } \\
\text { - As a teacher, show attitude and enthusiasm with full of } \\
\text { motivation. }\end{array}$ \\
\hline & \multirow[t]{2}{*}{ Apperception } & $\begin{array}{l}\text { - Observe the students' initial abilities on the topic to be } \\
\text { studied }\end{array}$ \\
\hline & & $\begin{array}{l}\text { - Allow students to ask questions and express opinions } \\
\text { related to the topic. }\end{array}$ \\
\hline & Delivering learning purpose & - Deliver the topics or purpose to be discussed in learning. \\
\hline \multirow{3}{*}{$\begin{array}{l}\text { General } \\
\text { exploration } \\
\text { (2) }\end{array}$} & Delivering general explanation & $\begin{array}{l}\text { - Deliver to the students the general description of the topic } \\
\text { with or without learning media. }\end{array}$ \\
\hline & \multirow[t]{2}{*}{$\begin{array}{l}\text { Conducting question and } \\
\text { answer (dialogue) about the } \\
\text { topics to be discussed }\end{array}$} & $\begin{array}{l}\text { - Give stimulus to students to make them respond, ask } \\
\text { questions (dialogue), or give opinions on topics to be } \\
\text { discussed. }\end{array}$ \\
\hline & & $\begin{array}{l}\text { - Invite students to understand or discuss the topics briefly } \\
\text { on the problem to be solved. }\end{array}$ \\
\hline \multirow{6}{*}{$\begin{array}{l}\text { Mastery of } \\
\text { learning } \\
\text { techniques } \\
\text { (3) }\end{array}$} & \multicolumn{2}{|c|}{$\begin{array}{l}\text { (this stage should not always be conducted in case students master the learning techniques to be } \\
\text { used or carried out at previous meetings. The teacher's task is only to provide an operational } \\
\text { understanding of the learning techniques) }\end{array}$} \\
\hline & \multirow[t]{3}{*}{ Explain learning techniques } & $\begin{array}{l}\text { - Explain the techniques to be used, operational procedures, } \\
\text { and an overview of learning outcomes. }\end{array}$ \\
\hline & & $\begin{array}{l}\text { - Give stimulus to students for them to ask questions related } \\
\text { to the learning method used. }\end{array}$ \\
\hline & & $\begin{array}{l}\text { - Give direction and guidance to students on how to learn in } \\
\text { groups, the importance of collaboration and } \\
\text { responsibilities in groups. }\end{array}$ \\
\hline & Explain students worksheet & - Briefly discuss the operational use of students worksheet \\
\hline & $\begin{array}{l}\text { Explain group - individual } \\
\text { learning techniques }\end{array}$ & $\begin{array}{l}\text { - } \text { Briefly explain the individual learning in groups. } \\
\text { - } \quad \text { Form groups using the jigsaw method }\end{array}$ \\
\hline \multirow{2}{*}{ Investigation } & \multicolumn{2}{|c|}{$\begin{array}{l}\text { (this stage is the core learning activity and should be carried out individually by students } \\
\text { collaborating in groups) }\end{array}$} \\
\hline & $\begin{array}{l}\text { Preparation of learning } \\
\text { activities }\end{array}$ & $\begin{array}{l}\text { - Observe that students are ready in the } 1^{\text {st }} \text { group to start } \\
\text { learning. }\end{array}$ \\
\hline
\end{tabular}




\begin{tabular}{|c|c|c|}
\hline & & $\begin{array}{l}\text { When students discuss worksheets, re-explain to students } \\
\text { about the problems that should be answered individually } \\
\text { or in groups. }\end{array}$ \\
\hline & $\begin{array}{l}\text { Conditioning problem solving } \\
\text { and collaboration activities }\end{array}$ & $\begin{array}{l}\text { Motivate students to be serious in solving the problem } \\
\text { individually in a group. }\end{array}$ \\
\hline & \multirow[t]{3}{*}{$\begin{array}{l}\text { Implement the learning } \\
\text { techniques and the process of } \\
\text { mastering lesson content }\end{array}$} & $\begin{array}{l}\text { Guide students individually in the } 1^{\text {st }} \text { group to solve } \\
\text { problems with scientific thinking procedures (formulate } \\
\text { problems and sub-problems, collect data, study data, and } \\
\text { formulate conclusions). Individual student work is written } \\
\text { in portfolio sheet } 1\end{array}$ \\
\hline & & $\begin{array}{l}\text { Conditioning help students choose one sub-topic or } \\
\text { problem to be studied with other groups (second group) }\end{array}$ \\
\hline & & $\begin{array}{l}\text { With the teacher's direction, students join the second } \\
\text { group studying the same sub-topic or problem. The results } \\
\text { of individual studies are written in portfolio sheet } 2\end{array}$ \\
\hline & Monitor the learning process & $\begin{array}{l}\text { - Walk around each group to observe, and give individual or } \\
\text { group direction. }\end{array}$ \\
\hline & Helping students difficulties & $\begin{array}{l}\text { Help students if they need learning resources that are } \\
\text { necessary for the class. }\end{array}$ \\
\hline & $\begin{array}{l}\text { Process / performance } \\
\text { evaluation }\end{array}$ & $\begin{array}{l}\text { - Conduct a process assessment of the activities carried out } \\
\text { in groups. }\end{array}$ \\
\hline & & - Remind them in case time for the activity is almost up. \\
\hline & & $\begin{array}{l}\text { After completing the study in the second group, direct } \\
\text { students to rejoin the } 1^{\text {st }} \text { group to answer general } \\
\text { problems. Make the group study results in portfolio sheet } \\
3\end{array}$ \\
\hline \multirow{3}{*}{$\begin{array}{l}\text { Evaluation and } \\
\text { follow up } \\
\qquad \text { (5) }\end{array}$} & Carry out the final test & - Give questions to several students as a final oral test \\
\hline & $\begin{array}{l}\text { Collect the results of individual } \\
\text { and group work }\end{array}$ & - Collection of student work individually or in groups \\
\hline & $\begin{array}{l}\text { Deliver the topic of the next } \\
\text { subject }\end{array}$ & - Deliver the topic to be studied in the next meeting \\
\hline
\end{tabular}

\subsection{Implementation Model}

Learning Implementation Model with Differentiated Group Learning in social science subjects at junior high schools can be described as follows; (a) Teacher and student activities have increased compared to conventional learning; (b) Procedures to be carried out in implementation include orientation, general exploration, mastery of learning techniques, investigation, evaluation, and follow-up; (c) The flexibility of curriculum elements (content, process, and results) is likely to be more dominant during the learning process; (d) Eliminating the weaknesses of both individual and group approaches; (e) Students are more confident.

Table 4: Syntax of Learning Implementation

\begin{tabular}{|l|l|l|}
\hline \multicolumn{1}{|c|}{ Procedure } & \multicolumn{1}{|c|}{ Details } & \multicolumn{1}{c|}{ Teacher's Scenario } \\
\hline $\begin{array}{l}\text { Orientation } \\
\text { (1) }\end{array}$ & $\begin{array}{l}\text { Creating conditions for } \\
\text { effective learning }\end{array}$ & $\begin{array}{l}\text { It starts from the beginning of learning by creating a conducive } \\
\text { classroom atmosphere for readiness to take lessons. }\end{array}$ \\
& & $\begin{array}{l}\text { Direct the concentration of students and encourage them to be } \\
\text { interested in learning. } \\
\text { - As a teacher, show attitude and enthusiasm with full of } \\
\text { motivation. }\end{array}$ \\
\cline { 2 - 3 } & Apperception & - Observe the students' initial abilities on the topic to be studied \\
\cline { 2 - 3 } & $\begin{array}{l}\text { - Allow students to ask questions and express opinions related to } \\
\text { the topic. }\end{array}$ \\
\cline { 2 - 4 } & Delivering learning purpose & - Deliver the topics or purpose to be discussed in learning. \\
\hline & Delivering general explanation & $-\begin{array}{l}\text { Deliver to the students the general description of the topic with } \\
\text { or without learning media. }\end{array}$ \\
\hline
\end{tabular}




\begin{tabular}{|c|c|c|}
\hline \multirow{2}{*}{$\begin{array}{l}\text { General } \\
\text { exploration } \\
\text { (2) }\end{array}$} & \multirow{2}{*}{$\begin{array}{l}\text { Conducting question and } \\
\text { answer (dialogue) about the } \\
\text { topics to be discussed }\end{array}$} & $\begin{array}{l}\text { - Give stimulus to students to make them respond, ask questions } \\
\text { (dialogue), or give opinions on topics to be discussed. }\end{array}$ \\
\hline & & $\begin{array}{l}\text { Invite students to understand or discuss the topics briefly on the } \\
\text { problem to be solved. }\end{array}$ \\
\hline \multirow{6}{*}{$\begin{array}{l}\text { Mastery of } \\
\text { learning } \\
\text { techniques } \\
\text { (3) }\end{array}$} & \multicolumn{2}{|c|}{$\begin{array}{l}\text { (this stage should not always be conducted in case students master the learning techniques to be used } \\
\text { or carried out at previous meetings. The teacher's task is only to provide an operational } \\
\text { understanding of the learning techniques ) }\end{array}$} \\
\hline & \multirow[t]{3}{*}{ Explain learning techniques } & $\begin{array}{l}\text { Explain the techniques to be used, operational procedures, and an } \\
\text { overview of learning outcomes. }\end{array}$ \\
\hline & & $\begin{array}{l}\text { - Give stimulus to students for them to ask questions related to the } \\
\text { learning method used. }\end{array}$ \\
\hline & & $\begin{array}{l}\text { - Give direction and guidance to students on how to learn in } \\
\text { groups, the importance of collaboration and responsibilities in } \\
\text { groups. }\end{array}$ \\
\hline & Explain students worksheet & - Briefly discuss the operational use of students worksheet \\
\hline & $\begin{array}{l}\text { Explain group - individual } \\
\text { learning techniques }\end{array}$ & $\begin{array}{l}\text { - } \quad \text { Briefly explain the individual learning in groups. } \\
\text { - } \quad \text { Form groups using the jigsaw method }\end{array}$ \\
\hline \multirow{15}{*}{ Investigation } & \multicolumn{2}{|c|}{$\begin{array}{l}\text { (this stage is the core learning activity and should be carried out individually by students collaborating } \\
\text { in groups) }\end{array}$} \\
\hline & \multirow{2}{*}{$\begin{array}{l}\text { Preparation of learning } \\
\text { activities }\end{array}$} & - Observe that students are ready in the $1^{\text {st }}$ group to start learning. \\
\hline & & $\begin{array}{l}\text { When students discuss worksheets, re-explain to students about } \\
\text { the problems that should be answered individually or in groups. }\end{array}$ \\
\hline & $\begin{array}{l}\text { Conditioning problem solving } \\
\text { and collaboration activities }\end{array}$ & $\begin{array}{l}\text { Motivate students to be serious in solving the problem } \\
\text { individually in a group. }\end{array}$ \\
\hline & \multirow[t]{3}{*}{$\begin{array}{l}\text { Implement the learning } \\
\text { techniques and the process of } \\
\text { mastering lesson content }\end{array}$} & $\begin{array}{l}\text { - Guide students individually in the } 1^{\text {st }} \text { group to solve problems } \\
\text { with scientific thinking procedures (formulate problems and } \\
\text { sub-problems, collect data, study data, and formulate } \\
\text { conclusions). Individual student work is written in portfolio } \\
\text { sheet } 1\end{array}$ \\
\hline & & $\begin{array}{l}\text { - Conditioning help students choose one sub-topic or problem to } \\
\text { be studied with other groups (second group) }\end{array}$ \\
\hline & & $\begin{array}{l}\text { - With the teacher's direction, students join the second group } \\
\text { studying the same sub-topic or problem. The results of } \\
\text { individual studies are written in portfolio sheet } 2\end{array}$ \\
\hline & Monitor the learning process & $\begin{array}{l}\text { - Walk around each group to observe, and give individual or } \\
\text { group direction. }\end{array}$ \\
\hline & Helping students difficulties & $\begin{array}{l}\text { - Help students if they need learning resources that are necessary } \\
\text { for the class. }\end{array}$ \\
\hline & $\begin{array}{l}\text { Process / performance } \\
\text { evaluation }\end{array}$ & $\begin{array}{l}\text { - Conduct a process assessment of the activities carried out in } \\
\text { groups. }\end{array}$ \\
\hline & & - Remind them in case time for the activity is almost up. \\
\hline & & $\begin{array}{l}\text { - After completing the study in the second group, direct students } \\
\text { to rejoin the } 1 \text { st group to answer general problems. Make the } \\
\text { group study results in portfolio sheet } 3\end{array}$ \\
\hline & Carry out the final test & - Give questions to several students as a final oral test \\
\hline & $\begin{array}{l}\text { Collect the results of } \\
\text { individual and group work }\end{array}$ & - Collection of student work individually or in groups \\
\hline & $\begin{array}{l}\text { Deliver the topic of the next } \\
\text { subject }\end{array}$ & - Deliver the topic to be studied in the next meeting \\
\hline
\end{tabular}




\subsection{Learning Environment Model}

The environmental condition contributes to the effectiveness of learning. The scope of the learning environment that supports starts from the conditions of the group, classroom, school, and community. Environmental standards and learning conditions that need attention include; 1) pleasant atmosphere in class; 2) activity and motivation in groups and class; 3) democratic class atmosphere; 4) discipline in the classroom; 5) effective school management; and 6) conducive community conditions. This finding is in line with [16] which detailed the support for learning environments, including a) pre-lesson conferences for joint lesson planning, b) core issues for lesson designs, c) both elements, or d) another educational topic (control group), effects on the quality of collaborative exchange in lesson conferences, student teachers' competency gains, and instructional quality.

Learning Environment Models [20] established in the differentiated group shows the existence of media empowerment and maximum learning resources support its success. Students are guided to search for and study data and information related to the topic, based on[21]. During the experiment class, especially at the second meeting, the data and information were obtained not only from textbooks but also from various sources. In general, the information contained in geography textbooks at that time tended to be less appropriate to the latest developments, such as charts, distribution maps, growth charts, and factual data [22]. During the second meeting, students and teachers were gradually encouraged to complete data and information that suits the latest developments.

\subsection{Model Testing Results in measuring Students' Thinking and Social abilities}

\section{- Cognitive Ability}

The level of students' ability to solve issues is evident in the process, and the results of problem-solving described in Using Metaphors to Aid Student Meta-Learning [16]. The results of problem-solving are classified by categories, including (1) knowledge ability, such as remembering data and information, (2) the ability to understand data and information, and (3) analysis and synthesis aptitude. From the first to the third learning on the large-scale testing of students' abilities, there was progress towards a higher level. In the first learning, students' ability mainly involved knowledge (cognitive; memory), while the ability of analysis, synthesis, or application was very little. In the subsequent learning, the analysis ability gradually increased. Many students showed an increase in the analysis and application ability in the third learning. This finding was in line with[16], which established that critical thinking is essential for success in all human endeavors. The details are shown in the table below.

Table 5: Recapitulation of Student Cognitive Ability Results Based on Study Large Scale Learning Testing Results

\begin{tabular}{|l|l|l|c|}
\hline \multirow{2}{*}{ Ability level } & \multicolumn{3}{|c|}{ Learning Stage } \\
\cline { 2 - 4 } & \multicolumn{1}{|c|}{ The First } & The Second & The Third \\
\hline Knowledge & $62.16 \%$ & $39.61 \%$ & $22.86 \%$ \\
\hline Understanding & $28.4 \%$ & $37.83 \%$ & $48.98 \%$ \\
\hline Analysis \& application. & $9.42 \%$ & $22.5 \%$ & $28.15 \%$ \\
\hline
\end{tabular}

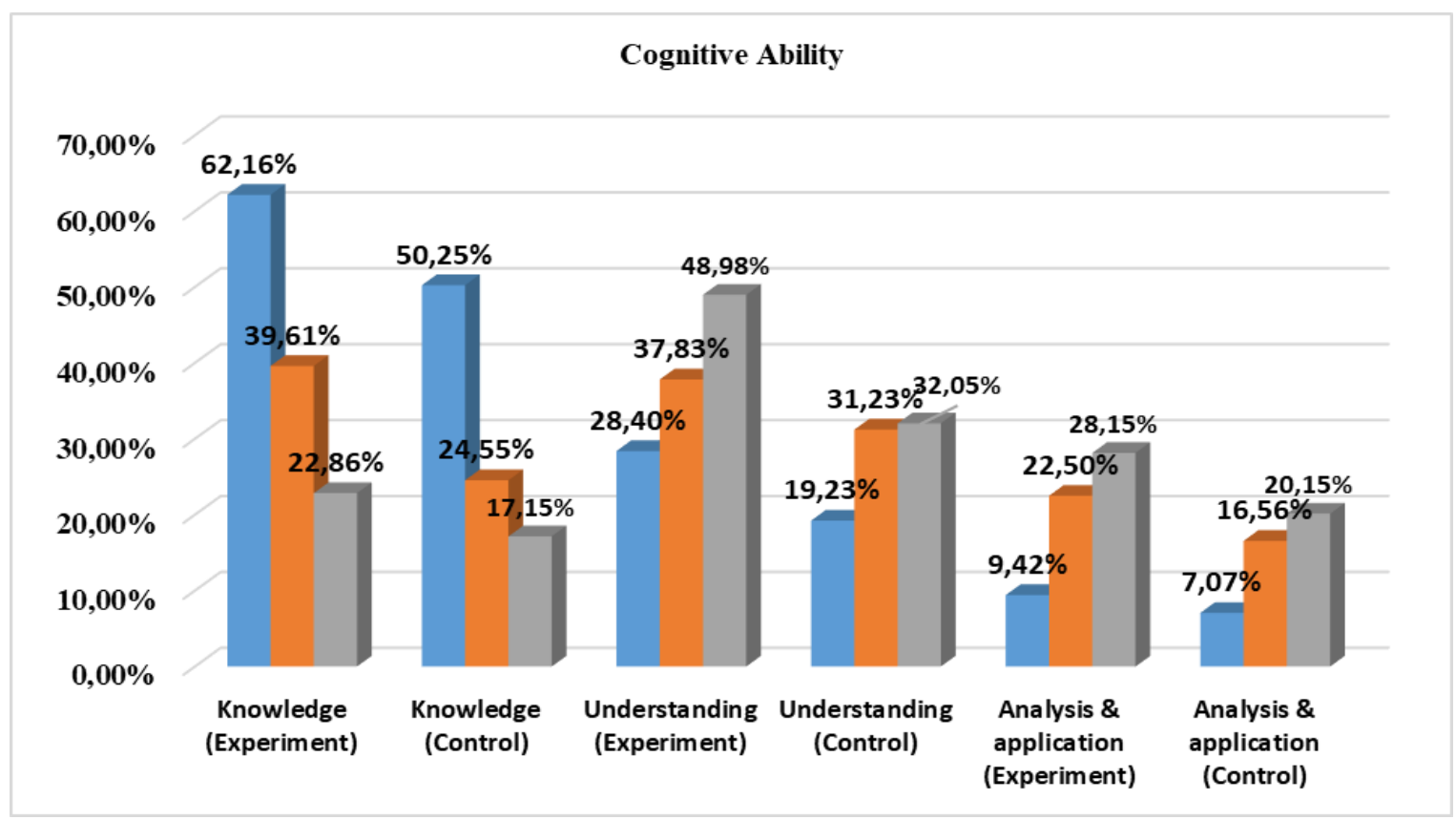

Figure 1: Student's Cognitive Ability Results Based on Experiment and Control Groups 


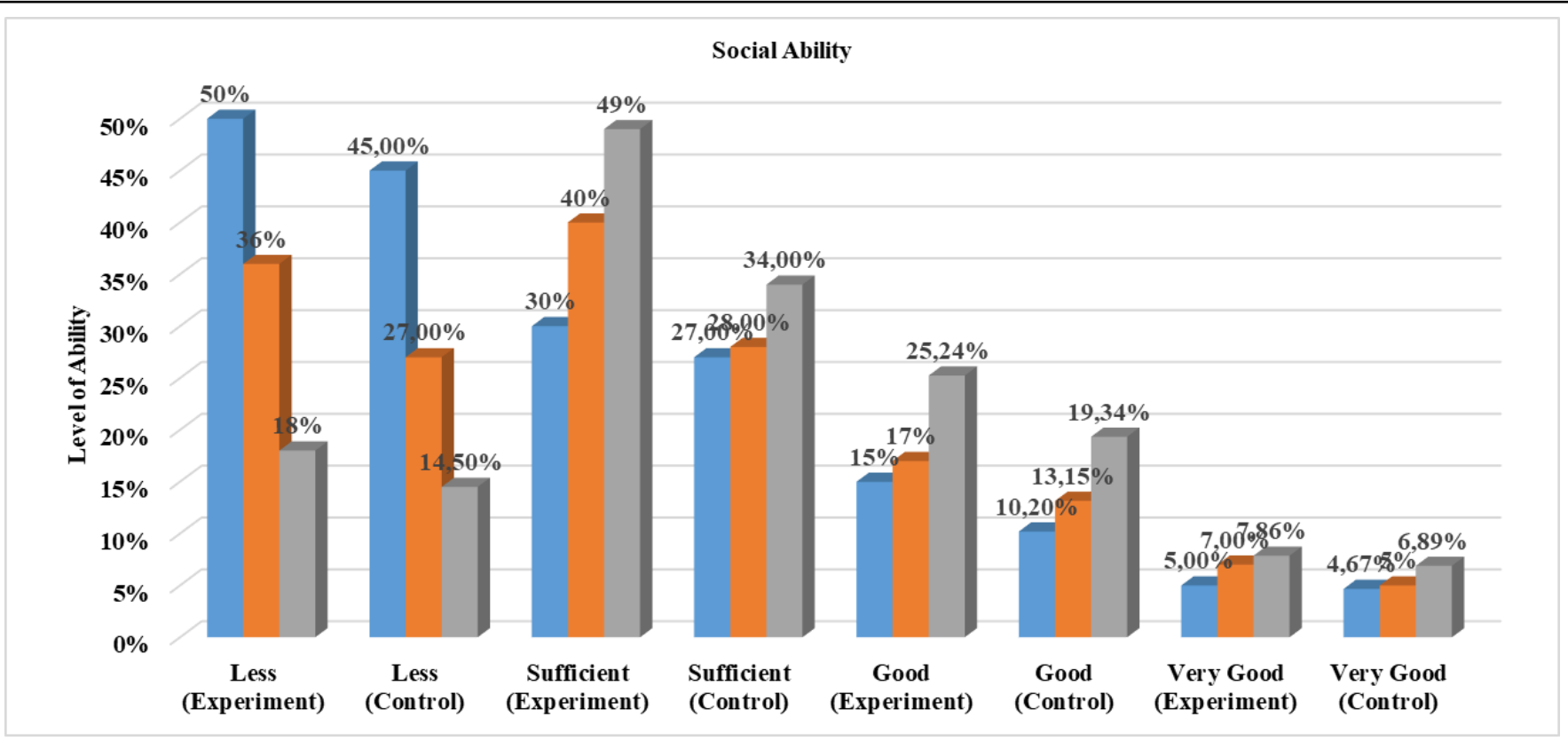

Figure 2: Student's Social Ability Results Based on Experiment and Control Groups

Table 6: Recapitulation of Students' Social Ability Results Based on the Study of Large Scale Learning Testing Results

\begin{tabular}{|l|l|l|l|}
\hline \multirow{2}{*}{ Ability level } & \multicolumn{3}{c|}{ Learning Stage } \\
\cline { 2 - 4 } & \multicolumn{1}{|c|}{ The First } & \multicolumn{1}{c|}{ The Second } & \multicolumn{1}{c|}{ The Third } \\
\hline Less & $50 \%$ & $36 \%$ & $18 \%$ \\
\hline Sufficient & $30 \%$ & $40 \%$ & $49 \%$ \\
\hline Good & $15 \%$ & $17 \%$ & $25.24 \%$ \\
\hline Very Good & 5 & 7 & 7.86 \\
\hline
\end{tabular}

Table 7: Objective Test Results in Experiment and Control Groups

\begin{tabular}{|l|l|l|l|l|l|l|l|l|l|}
\hline & \multicolumn{1}{|c|}{$\mathrm{N}$} & Minimum & Maximum & Mean & \multicolumn{1}{|c|}{ Std. } & \multicolumn{2}{|c|}{ Skewness } & \multicolumn{2}{|c|}{ Kurtosis } \\
\cline { 2 - 9 } & Statistic & Statistic & Statistic & Statistic & $\begin{array}{l}\text { Deviation } \\
\text { Statistic }\end{array}$ & Statistic & $\begin{array}{c}\text { Std. } \\
\text { Error }\end{array}$ & $\begin{array}{c}\text { Statistic } \\
\text { Std. } \\
\text { Error }\end{array}$ \\
\hline Pretest-Experiment & 92 & 2.80 & 5.20 & 3.9641 & .52927 & -.063 & .251 & -.485 & .498 \\
\hline Pretest-Control & 92 & 2.80 & 5.00 & 3.7935 & .61301 & .404 & .251 & -.843 & .498 \\
\hline Post Test-Experiment & 92 & 6.00 & 8.40 & 7.4196 & .50758 & -.170 & .251 & -.683 & .498 \\
\hline Posttest-Control & 92 & 5.80 & 8.00 & 6.8717 & .53807 & -.030 & .251 & -.394 & .498 \\
\hline School & 92 & 1 & 2 & 1.50 & .503 .503 & .000 & .251 & -2.045 & .498 \\
\hline Gain-Experiment & 92 & .20 & .71 & .4891 & .11282 & -.600 & .251 & .153 & .498 \\
\hline Gain-Control & 92 & .37 & .74 & .5693 & .09251 & -.283 & .251 & -.813 & .498 \\
\hline Valid N (list wise) & 92 & & & & & & & \\
\hline
\end{tabular}

Table 8: Descriptive Test Result in Experimental and Control Groups

\begin{tabular}{|c|c|c|c|c|c|c|c|c|}
\hline & $\mathrm{N}$ & Mean & Std. & Variance & \multicolumn{2}{|r|}{ Skewness } & \multicolumn{2}{|r|}{ Kurtosis } \\
\hline & Statistic & Statistic & $\begin{array}{r}\text { Deviation } \\
\text { Statistic }\end{array}$ & Statistic & Statistic & $\begin{array}{r}\text { Std. } \\
\text { Error }\end{array}$ & Statistic & $\begin{array}{r}\text { Std. } \\
\text { Error }\end{array}$ \\
\hline Pretest-Experiment & 92 & 4.2239 & .57919 & .335 & -.027 & .251 & -.295 & .498 \\
\hline Pretest-Control & 92 & 4.1185 & .64124 & .11 & .145 & .251 & -.893 & .498 \\
\hline Post Test-Experiment & 92 & 7.2978 & 1.0059 & 1.012 & -.604 & .251 & -.009 & .498 \\
\hline Posttest-Control & 92 & 5.9793 & 1.04729 & 1.097 & -.264 & .251 & -1.049 & .498 \\
\hline Gain-Experiment & 92 & .5319 & .15943 & .025 & -.359 & .251 & .263 & .498 \\
\hline Gain-Control & 92 & .3179 & .16273 & .026 & -.117 & .251 & -.188 & .498 \\
\hline Valid N (list wise) & 92 & & & & & & & \\
\hline
\end{tabular}


Table 5 and figure 1, shows that in the first learning, the results of problem-solving by the student (individual) were more on knowledge (remembering) (62.16\%). The ability to analyze was only around 39\%. This finding was in line with (Savage 2019), which focused on student achievement and [23] on high-level thinking and learning outcomes of learners who have been analyzed using N-Gain.

\section{- Social Ability}

The table above shows that in learning, the level of social ability of some students was less $(50 \%)$. Students with excellent social abilities were only $15 \%$. In contrast to the third learning, the level of social ability of students was high.

The table.7 above shows that the averages for the pretest, posttest, and gain for the experimental group were $3.9641 ; 7.4196$, and 0.5693 , while the control groups had 3.7935; 6.8717, and 0.4891 respectively. Based on these results, the average ability of the experimental group both at pretest and posttest was slightly higher than the control group. Another aspect that should be considered is data dissemination. Data (pretest, posttest, and gain) in the control class tended to be more spread than in the experimental group. The description of learning outcomes data is shown in the following table 8 .

Analysis of learning outcomes through tests with description is almost the same as the tests with an objective form, showing the consistency of students' abilities in learning outcomes. Based on the size of the central tendency, the average ability of the experimental group was higher than the control group, both in the pretest, post-test, and gain.

This research and development were meant to produce a learning model that could serve students' differences and optimize individual learners' potential in thinking and social abilities. The essence of the model was learning based on students' and cooperative differences. Several assumptions underlie this learning, including 1) Individual development is a matter that needs to be considered in teaching, in this case, the position of students as individuals and social beings who need to socialize [24], [25]; 2) in learning it is necessary to develop democratic processes that can be carried out by students through scientific methods, [26]; 3) through group study, students can exchange knowledge, experience, and views, develop feelings, attitudes, and beliefs, working together and increasing motivation[14]; 4) 11-15 years old children, including those in the formal operation phase, have stages of intellectual development that need problemsolving techniques in learning (Piaget); 5) learning implementation needs to recognize and develop students 'abilities based on their multiple intelligence [13].

This learning model can be implemented in regular classes or the Class of Excellence. It can optimize students' abilities through acceleration, escalation, or enrichment, and can serve learning activities that are compatible with the diversity of students' interests. It can assist teachers to develop and improve students' abilities in regular classes, this result support from [27]. This is proven by students who participated in the learning model. Many students $(>50 \%)$ gained improvement and deepening from the ability of basic level knowledge to analyze and synthesize, [28],
[29]. The formation of rational abilities can be developed through problem-solving activities in teaching and learning events adjusted to the level of student progress, this result support by [30]. The problem-solving activities by investigating (reviewing) data and information from the media and learning resources,[31] were appropriate and can be implemented to junior high school students. The investigative approach in learning is an integral part of problem-solving activities that implement the principles of democracy to the scientific method and inquiry as a learning process,[32]. The characteristics of learning activities developed further provide opportunities for individual learning that synergizes with groups to be carried out optimally according to student potential. This finding was in line with [33], which discussed how to support learning for measurable positive impacts on teaching quality and teacher morale. Therefore, it is necessary to implement the principles of democracy, competitive, and cooperative developed in the learning process, which leads to the formation of higher-order thinking skills and social abilities.

\section{Conclusion and Recommendation}

GBDL models which optimize students' thinking and social abilities based on an individual potential focus on aspects of competency; Problem based learning and individual learning in groups. Students understand the individual and group learning techniques, as well as the teacher design. The learning objectives are developed in the form of measurable and specific abilities describing student behavior. The design of the learning process is developed in stages systematically and follows several activities, including orientation, general exploration; practice (mastery) of learning techniques; investigation, evaluation, and; follow-up. Learning design components of GDBL include (a) Analysis of characteristics and curriculum elements; (b) Learning objectives or competencies to be achieved; (c) Essential material; (d) Learning Process; (e) Learning Evaluation. Learning implementation models of GBDL which optimizes students' thinking and social abilities are developed in the following stages, (a) Learning syntax procedures; (b) An integrated manner guided by student worksheet (SW) and the teacher; (c) The group approach is implemented into 2 models, the first and the second groups. The process requires students to learn individually, collaborating in groups; (d) Alternative effective learning strategies used in this learning include problem-solving, inquiry, and group study. Learning environment standards that optimize students' thinking and social abilities based on an individual potential focus on the standard conditions of the learning environment relating to students, teachers, and essential subject matter. This makes the learning environment to be oriented to the activities of the study and the creation of relevant learning resources.

The findings of the GBDL model are expected to be used by teachers when teaching with the group learning method. Especially in social science learning which refers to the use of natural learning resources at the junior high school level.

\section{Conflict of Interest}

The authors declare no conflict of interest.

\section{Acknowledgment}

The author would like to express gratitude to the Ministry of Research and Technology of Indonesia that has provided research 
grants of Post graduate School of the Universitas Pendidikan Indonesia, who has permitted to complete this research to provide benefits in the world of education.

\section{References}

[1] A. C. Vilasi, "Intelligence, Globalization, Complex and Multi-Level Society," Open J. Polit. Sci., 08(1), 47-56, 2018, doi: 10.4236/ojps.2018.81004.

[2] J. A. de Ruiter, A. M. G. Poorthuis, and H. M. Y. Koomen, "Relevant classroom events for teachers: A study of student characteristics, student behaviors, and associated teacher emotions," Teach. Teach. Educ., 86(2), p. 102899, 2019, doi: 10.1016/j.tate.2019.102899.

[3] V. B. Ngalim, "Harmonization of the Educational Sub-Systems of Cameroon: A Multicultural Perspective for Democratic Education," . Creative Education, 04(1), 334-346, 2014.

[4] S. Mohammad and A. Jado, "The Level of Multiple Intelligences in Arabic Language Textbooks for Grades from ( 1 - 4 ) in Jordan in Light of Gardner 's Theory," 08(1), 1558-1572, 2015.

[5] M. R. Wadaani, "Teaching for Creativity as Human Development toward Self-Actualization: The Essence of Authentic Learning and Optimal Growth for All Students,"., 07(5), 669-679, 2015.

[6] M. E. M. Bernardes, "Active Teaching Approach: Teaching and Learning Methods on Historical and Cultural Theory," Creat. Educ., 05(10), 734742, 2014, doi: 10.4236/ce.2014.510086.

[7] C. A. Tomlinson, "The differrentiated classroom, Responding to needs of all learner.," Alexandria, VA. USA.ASCD, 2019.

[8] Gardner.H., "Multiple Intelligences the Theory in Practice," New york Prentice-Hall Co., 1993.

[9] D. M. Biddle.B, "The Studi of Teaching," New York Holt, Renehart Winston., 2004.

[10] F. Hellen et al., "Working with Creativity of Gifted Students through Ludic Teaching,". Online Submission, 07(2), 1641-1647, 2016.

[11] F. Egert, V. Dederer, and R. G. Fukkink, "The impact of in-service professional development on the quality of teacher-child interactions in early education and care : A meta- analysis," Educ. Res. Rev., 29(11), 100309, 2020, doi: 10.1016/j.edurev.2019.100309.

[12] T. Stoltz et al., "Creativity in Gifted Education: Contributions from Vygotsky and Piaget,",,05(1), 64-70, 2015.

[13] S. S. Kavanagh, C. Monte-Sano, A. Reisman, B. Fogo, S. McGrew, and P. Cipparone, "Teaching content in practice: Investigating rehearsals of social studies discussions," Teach. Teach. Educ., 86(2), 102863, 2019, doi: 10.1016/j.tate.2019.06.017.

[14] B. and W. M. Joyce, Models of Teaching, New Jersey Prentice Hall., 1996.

[15] C. C. Deneen, G. W. Fulmer, G. T. L. Brown, K. Tan, W. S. Leong, and H. Y. Tay, "Value, practice and proficiency: Teachers' complex relationship with assessment for learning," Teach. Teach. Educ., 80(2), 39-47, 2019, doi: 10.1016/j.tate.2018.12.022.

[16] H. P. A. Boshuizen, H. Gruber, and J. Strasser, "Knowledge restructuring through case processing: The key to generalise expertise development theory across domains?," Educ. Res. Rev., 29(1), 100310, 2020, doi: 10.1016/j.edurev.2020.100310.

[17] W. R. B. Gall, Meredith D., J.P. Gall, Educational Research: An Introduction, NY Pearson Educ. Inc., 2003.

[18] L. W. \& K. D. R. A. Anderson, Taxonomy for Learning Teaching and Assessing, New York Addison Wesley Longman,Inc, 2002.

[19] M. Borg, R.W., Gall, Educational Research An Introduction. 5ed, Longman, Newyork, 2019.

[20] W. Zhao, "Paradigm of Foreign Language Teaching and Learning: A Perspective of Self-Regulated Learning Environment Construction," 05(1), 167-177, 2016.

[21] N. M. Ardoin and A. W. Bowers, "Early childhood environmental education : A systematic review of the research literature," Educ. Res. Rev., 31 (7), 100353, 2020, doi: 10.1016/j.edurev.2020.100353.

[22] C. Kivunja, "Creative Engagement of Digital Learners with Gardner's Bodily-Kinesthetic Intelligence to Enhance Their Critical Thinking," Creat. Educ., 06(6), 612-622, 2015, doi: 10.4236/ce.2015.66060.

[23] A. Ambarita, E. Liana, and C. Ertikanto, "Development Problem Based Learning to Increase Skill Thinking High Levels," Open J. Soc. Sci., 06(10), 34-49, 2018, doi: 10.4236/jss.2018.610004.

[24] O. Costache, E. Becker, F. Staub, and T. Mainhard, "Using uncertainty as a learning opportunity during pre-lesson conferences in the teaching practicum," Teach. Teach. Educ., 86(2), 102890, 2019, doi: 10.1016/j.tate.2019.102890.

[25] H. Taba, Curriculum Development: theory and practice, New York Harcourt, Brace world, Inc Atlanta., 1962.

[26] J. Dewey, How We Think, Heeath. Bost., 1992.

[27] M. D. Ilie et al., "Reviewing the research on instructional development programs for academics . Trying to tell a different story : A meta-analysis," Educ. Res. Rev., 30 (3), 100331, 2020, doi: 10.1016/j.edurev.2020.100331.

[28] Stamatios Papadakis and Michail Kalogiannakis, "A Research Synthesis of the Real Value of Self-Proclaimed Mobile Educational Applications for Young Children,” Mob. Learn. Appl. Early Child. Educ., 07(5),p. 19, 2020 , doi: 10.4018/978-1-7998-1486-3.ch001.

[29] W. Pardjono, "Improving the Capability of Analysis, Synthesis, and Evaluation Through Problem Solving Learning," Yogyakarta Univ. Negeri Yogyakarta, 2009.

[30] M. A. Veldman, S. Doolaard, R. J. Bosker, and T. A. B. Snijders, "Young children working together . Cooperative learning effects on group work of children in Grade 1 of primary education," Learn. Instr., 67(2), 101308, 2020, doi: 10.1016/j.learninstruc.2020.101308.

[31] J. M. Thomson, N. Foldnes, P. Henning, M. Njå, O. Judith, and K. Lundetræ, "Can children's instructional gameplay activity be used as a predictive indicator of reading skills?," Learn. Instr., 68(11), 101348, 2020, doi: 10.1016/j.learninstruc.2020.101348.

[32] S. Becker, P. Klein, A. Gößling, and J. Kuhn, "Using mobile devices to enhance inquiry-based learning processes $\downarrow$, , Learn. Instr., 69(6), 101350, 2020, doi: 10.1016/j.learninstruc.2020.101350.

[33] J. Gore, A. Lloyd, M. Smith, J. Bowe, H. Ellis, and D. Lubans, "Effects of professional development on the quality of teaching: Results from a randomised controlled trial of Quality Teaching Rounds," Teach. Teach. Educ., 68(8), 99-113, 2017, doi: 10.1016/j.tate.2017.08.007. 